\title{
Šanghajski geto in zgodovinsko ter politično ozadje judovskih beguncev iz Tretjega rajha v letih 1933-1945
}

\author{
Matjaž VIDMAR*
}

\section{Izvleček}

Pričujoči članek predstavi usodo skoraj 20.000 judovskih beguncev v Šanghaju v času Tretjega rajha. Šanghajski eksil je edinstven zaradi dejstva, da so judovski begunci v mednarodne enklave lahko vstopili brez vizuma do jeseni leta 1939. V najbolj kritičnem letu 1938 je bil zaradi nevtralne drže mednarodnih enklav Šanghaj edini kraj na svetu, kamor so Judje lahko vstopili brez vizuma, zato je bilo priseljevanje v tem letu največje. Članek obravnava tudi življenjske razmere beguncev v okupiranem Šanghaju, politiko Japonske do Judov in ob koncu osvetljuje ozadje razglasitve šanghajskega geta $\mathrm{v}$ japonski četrti Hongkou.

Ključne besede: šanghajski eksil, judovska emigracija, šanghajski geto, kolonialni Šanghaj, Tretji rajh

\section{Abstract}

The article presents the fate of nearly 20.000 Jewish refugees in Shanghai during the Third Reich. Shanghai exile was unique because Jewish refugees were able to enter international enclaves without visa until the autumn of 1939. Due to the International Settlement's policy of neutrality, Shanghai was in the most critical year of 1938 the only area in the world, where Jews were allowed to enter without visa, which caused mass immigration in this crucial time. The article also deals with living conditions in the occupied Shanghai, the Japanese policy towards Jews and illuminates the proclamation of Shanghai ghetto in the Japanese concession Hongkou.

Keywords: Shanghai exile, Jewish emigration, Shanghai ghetto, colonial Shanghai, the Third Reich

\footnotetext{
* Matjaž Vidmar, univ. dipl. sinolog in profesor nemščine, mladi raziskovalec na Oddelku za azijske in afriške študije, Filozofska fakulteta, Univerza v Ljubljani.

matjaz.vidmar@ff.uni-lj.si
} 


\section{Uvod}

Šanghajski eksil vsekakor spada med manj znana poglavja emigracije iz Tretjega rajha. V nasprotju z emigracijo v ZDA, Palestino, Veliko Britanijo, Francijo in druge države zahodne poloble pa temu delu zgodovine judovske emigracije še ni bilo namenjene velike pozornosti. K temu je vsekakor pripomoglo dejstvo, da se šanghajski emigranti niso ustalili na Kitajskem in so skoraj v celoti kmalu po ustanovitvi Ljudske republike Kitajske ponovno emigrirali. Z leti je njihova izkušnja utonila v pozabo. Drugi razlog je izobrazbena struktura teh izseljencev. V ZDA, Francijo, Turčijo, Veliko Britanijo in Mehiko so emigrirala prominentna imena iz različnih področij znanosti in umetnosti, kot so npr. Albert Einstein, Anna Seghers, Henry Kissinger, Sigmund Freud in drugi. Med šanghajskimi emigranti, ki so bili pretežno judovskega rodu, pa ni bilo tako slavnih oseb. Večinoma so pripadali srednjemu meščanskemu razredu. Znani umetniki, znanstveniki in kulturniki so brez težav emigrirali $\mathrm{v}$ bolj zaželene države, večinoma v ZDA, zato se nihče izmed njih ni odločil za manj zaželeno emigracijo v Šanghaj. Kljub temu si ta del zgodovine zasluži več pozornosti s strani raziskovalcev. Pionirsko delo raziskav o šanghajskem eksilu Davida Kranzlerja Japanese, Nazis \& Jews: the Jewish Refugee Community of Šanghaj, 1938-1945 kljub letnici 1976 še vedno velja za osrednje delo šanghajske emigracije. V zadnjih desetletjih je bilo izvedenih več raziskav v Nemčiji in Avstriji, med katerimi izstopata magistrsko delo Astrid Freyeisen o prisotnosti nacistične stranke v Šanghaju in monografija Elisabeth Buxbaum o kulturnem udejstvovanju beguncev. Pričujoči članek bo slovenski javnosti predstavil zgodovinsko in politično ozadje emigracije, ki pri nas doslej še ni bila podrobneje raziskana.

\section{Priseljevanje Judov v Šanghaj}

Sprejemanje judovskih beguncev je omogočila posebna administrativna ureditev Šanghaja, ki je bil razdeljen na tri administrativne enote. Tuje oblasti so se odločile za načelno nevtralnost $\mathrm{v}$ številnih mednarodnih konfliktih. Podoben potencialni konflikt med velesilami, ki bi lahko izbruhnil ob morebitni popolni kolonizaciji Kitajske, bi se lahko na manjšem območju zgodil tudi v Šanghaju. Zato so se mednarodne enklave vedno skušale izogniti konfliktom in so praviloma vojaško posredovale le v obrambnih situacijah. Politične odločitve so bile predvsem v mednarodni naselbini dokaj neodvisne od matičnih držav, zato se politike omejevanja priseljevanja niso razširile v Šanghaj. Za prihod v Šanghaj ni bilo treba predložiti vizuma. Posledica nevtralnosti Šanghaja v raznih konfliktih je 
bila, da so mednarodne enklave sprejemale veliko število beguncev iz Kitajske in iz tujine. Največji val beguncev iz tujine je Šanghaj sprejel proti koncu tridesetih let, ko so v kitajski metropoli zatočišče našli judovski emigranti iz Tretjega rajha. $\mathrm{V}$ času po novembrskih pogromih leta 1938 so bile mednarodne koncesije $\mathrm{v}$ Šanghaju edini kraj na svetu, kamor so Judje lahko pribežali brez vizuma.

\section{Administrativna ureditev Šanghaja}

Francoska koncesija ( $f a$ zujie 法租界) je bila ustanovljena leta 1849, mednarodna koncesija (gonggong zujie 公共租界) pa leta 1863. Pred tem sta že obstajali Britanska in Ameriška koncesija, ki pa sta se zaradi skupnih interesov združili (Freyeisen 2000, 18). Prvotno so tuje koncesije obsegale majhen pas ob reki Huangpu, ki je segal od sotočja reke Huangpu in potoka Suzhou do starega mestnega jedra, ki se je nahajal okoli današnjih vrtov Yuyuan (豫园). Najdlje v notranjost je tuja administracija segla na ulici Nanjing (南京路). Tuji koncesiji je obdajal kitajski Šanghaj, ki je v začetku obsegal le staro mestno jedro. Vzporedno z gospodarskim vzponom Šanghaja in zaradi številnih vojn je kitajski del Šanghaja po prebivalstvu hitro prekašal tuje enklave. Po ponovni združitvi Kitajske pod nacionalistično vlado $\mathrm{v}$ Nanjingu (南京) se je kitajski del mesta preimenoval v Veliki Šanghaj. Župan tega dela Šanghaja je bil neposredno odgovoren kitajski vladi. V začetku so lahko tujci le najemali zemljo, ki je sicer pripadala cesarju, že po Drugi opijski vojni pa so lahko kupovali zemljo in gradili lastne hiše. (Hawks Pott 2008, 13). Francoska koncesija je leta 1862 ustanovila mestni svet, toda pravo moč je imel francoski konzul, ki je imel pravico veta na odločitve mestnega sveta. V mednarodni naselbini se je mestni svet imenoval Shanghai Municipal Council (SMC). Imel je odločilno politično moč v mednarodni enklavi (Hawks Pott 2008, 18). Člani sveta niso bili izvoljeni demokratično, le trije odstotki tujcev so smeli prisostvovati volitvam v SMC. Kitajci do dvajsetih let niso imeli svojih predstavnikov. SMC je bil izvoljen v Skupščini tujih davkoplačevalcev (Meeting of Ratepayers), ki je bila sestavljena iz lastnikov največjih podjetij ter veleposestnikov. To je praktično zagotavljalo diktat kapitala v SMC-ju. V Skupščini tujih davkoplačevalcev so od leta 1926 od štirinajstih članov sedeli tudi trije Kitajci, leta 1937 pa pet. SMC tudi ni bil popolnoma neodvisen in tuji konzuli so imeli pravico revizije odločitev (Hawks Pott 2008, 138-42). 
Po Vstaji Taiping ${ }^{1}$ je bilo zaradi množičnega priseljevanja Kitajcev $\mathrm{v}$ tuje naselbine ustanovljeno mešano sodišče, ki je bilo pristojno za $\mathrm{v}$ mednarodnih enklavah živeče Kitajce. Sodne procese so nadzorovali tuji sodniki (Hawks Pott 2008, 67). Posebne pravice, ki so jih uživali tujci v Šanghaju, so bile eksteritorialne pravice, podrejenost mednarodnemu pravu in ne kitajski jurisdikciji ter prepoved vstopa kitajske vojske na območje tujih koncesij. Trgovinske pravice, ki so si jih izborili tujci, so omogočale hitro bogatenje. Tujci so bili poleg carine in najemnin oproščeni davkov, zato so bili šanghajski tujci praviloma bogatejši kot rojaki v matičnih državah. Pristojnosti SMC-ja so obsegale davčno izterjavo, javna dela, policijo, zdravstvo, šolstvo, gasilce ter prostovoljno obrambno četo, ki je bila sestavljena iz vseh narodnosti v Šanghaju. Po Boksarski vstaji so upravljali tudi s tujo garnizijo. $\mathrm{V}$ mednarodnih enklavah ni bilo zagotovljenega socialnega varstva, zato so v kriznih časih ljudje pogosto umirali kar na ulicah. Slabo organizirana prostovoljna karitativna dejavnost ni zmogla skrbeti za množice beguncev, ki so v kriznih časih preplavili mednarodne enklave. Zaradi nemogočih nastanitvenih in sanitarnih razmer je mestna policija mednarodne naselbine leta 1935 naštela kar 20.000 smrtnih žrtev na šanghajskih ulicah, med njimi tudi mnogo otrok, ki so večinoma umrli zaradi mraza in podhranjenosti (Freyeisen 2000, 27).

Prva večja razširitev mednarodnih enklav se je izvedla po letu 1899, ko se je zaradi posledic Sporazuma v Shimonosekiju ${ }^{2}$ število tovarn drastično povečalo. Tudi število prebivalcev je skokovito naraslo. Tuje enklave so se povečale za trikratnik. Francoska koncesija se je razširila na zahod do današnjega Xujiahuija (徐家汇), mednarodna koncesija pa na sever in severovzhod v četrti Zhabei (闸北) in Hongkou (虹口). Nova razširitev mednarodne uprave se je zgodila leta 1910. V takšnem obsegu so mednarodne enklave obstajale vse do konca mednarodnih privilegijev leta 1943 (Freyeisen 2000, 18-21).

\section{Emigracija Judov v Šanghaj}

Za Jude v Tretjem rajhu, ki so razmišljali o emigraciji, Šanghaj nikakor ni bil prvi kraj, na katerega so pomislili. Toda po novembrskih pogromih leta 1938, ko je

\footnotetext{
${ }^{1}$ Uporniško gibanje sredi 19. stoletja, ki je dodobra zamajalo centralno oblast. Z veliko vojsko so osvojili ozemlja v srednjem toku Modre reke in za kratek čas celo proglasili državo Tianguo 天国. Po napadih uporniške vojske na Šanghaj se je močno povečalo število beguncev v mestu.

${ }^{2} \mathrm{~S}$ tem sporazumom je Kitajska sprejela ponižujoče zahteve: Neodvisnost Koreje, vojno odškodnino, odprtje štirih novih pristanišč ter pravico Japoncev, da na Kitajskem odpirajo tovarne. Sporazum v Shimonosekiju je zaradi klavzule o največjih ugodnostih prinesel privilegije vsem preostalim tujim velesilam, kar je tuja podjetja postavilo v superioren položaj napram kitajskemu gospodarstvu.
} 
pravno diskriminacijo nadomestilo nasilje, je še največjim optimistom postalo jasno, da je treba zapustiti Hitlerjevo Nemčijo. Že sredi leta 1938 mednarodna skupnost ni uspela zaščititi beguncev na Konferenci v Évianu ${ }^{3}$, v najtežjih trenutkih so skoraj vse države dobesedno pred nosom zaprle vrata judovskim beguncem. Hitro se je med Judi v Tretjem rajhu razširila vest, da za prihod v Šanghaj ni treba urediti nikakršnih dokumentov. Celo osebe brez državljanstva ${ }^{4}$ so lahko prišle v Šanghaj. Točno število emigrantov v Šanghaju variira glede na različne vire. Pionir raziskav o šanghajskem eksilu, David Kranzler, navaja število med 17.000 in 18.000 (Kranzler 1976, 21), drugi viri ne presežejo števila 25.000. Med njimi je bilo tudi nekaj »arijskih« Nemcev, ki so bili v zakonski zvezi z Judi, ter kakih 1000 poljskih Judov. Že pred prihodom Judov iz Tretjega rajha sta $\mathrm{v}$ Šanghaju živeli dve judovski skupnosti.

\section{Kulturne kategorije šanghajskih Judov pred begunci iz Tretjega rajha}

Skupina Sefardov se je v Šanghaju naselila med prvimi tujimi priseljenci in je bila izjemno vplivna ter se je $\mathrm{z}$ leti povzpela $\mathrm{v}$ sam vrh šanghajske družbe. Med letom 1820 in prvo svetovno vojno so se bagdadski Sefardi, imenovani tudi Bagdadi, množično selili na Daljni vzhod. Med ciljnimi državami so bile Indija, Kitajska, države na Malajskem polotoku ter Japonska. Zaradi tesne povezanosti znotraj družine so sefardski Judje v Vzhodni Aziji ustanovili prave dinastije. Tak primer je bila družina Sasoon v Šanghaju, ki je bila najvplivnejša družina na Daljnem vzhodu do leta 1949. David Sasoon je bil potomec bagdadskih trgovcev. Leta 1832 se je ustalil v indijskem Bombaju. Pod britansko krono se je ukvarjal z bančništvom in trgovino. Svoje sinove je poslal na Kitajsko, ker je zaznal izjemno priložnost, ki jo je omogočilo odprtje kitajskih mest po sporazumu v Nanjingu. Tako se je njegov sin Elias David Sasoon leta 1850 ustalil v Šanghaju. Njegovo podjetje David Sasoon and Sons je imelo podružnice v vseh za trgovino odprtih kitajskih mestih ter na Japonskem in v Indiji. Zaposlovali so le ozek krog družinskih članov ter drugih bagdadskih Judov. V začetku so se kot večina drugih trgovcev ukvarjali s trgovino z opijem, kasneje pa je družina Sasoon razširila svoje

\footnotetext{
${ }^{3}$ Konferenca v Évianu je bila sklicana kot odgovor na Hitlerjevo priključitev Avstrije. Sosednje države so preplavili judovski begunci. Konferenca ni prinesla nobenih praktičnih rešitev za problem judovskih beguncev. Ko so začele nekatere vzhodnoevropske države na čelu s Poljsko iskati države gostiteljice za lastno judovsko prebivalstvo, se je število potencialnih beguncev povzpelo s pol milijona na nekaj milijonov. Humanitarni naboj konference, kjer naj bi reševali vprašanje judovskih beguncev, se je sprevrgel v $» j u d o v s k o$ vprašanje«, kar paradoksalno spominja na retoriko Tretjega rajha.

${ }^{4}$ Poljski Judje, ki sta jim obe državi odrekli državljanstvo.
} 
dejavnosti tudi na hotelirstvo in na nepremičninski trg. Sasoonovi so imeli v lasti nekaj najbolj prestižnih stavb na promenadi Bund (外滩). Zaradi gospodarskega vzpona Šanghaja se je v naslednjih desetletjih v Šanghaj priselilo okoli 700 Sefardov. Sasoonovi so bili pionirji, toda tudi druge sefardske družine, ki so se priselile kasneje, so dosegle zavidljivo blaginjo. Kljub temu pa ostali Sefardi razen nekaterih družin niso bili tako bogati, večinoma so bili zaposleni v večjih podjetjih bogatejših kolegov. Večina sefardskih Judov je imela britansko državljanstvo. Član družine Sasoon je vedno sedel v šanghajskem mestnem svetu (Shanghai municipal council ali SMC). Nekaj se jih je leta 1924 odločilo tudi za prevzem španskega državljanstva, ki ga je Španija ponudila leta 1492 iz Španije izgnanim sefardskim Judom (Kranzler 1976, 45-48).

Najvplivnejše judovske družine v Šanghaju so dosegle izjemno blagostanje in njihov prispevek k zdravstvu, šolstvu in kulturnemu življenju v Šanghaju je bil nepogrešljiv. Zgradili so več šol, leta 1934 tudi kliniko, ki je bila v času emigracije iz Tretjega rajha nepogrešljiva, ter knjižnico. Tudi za človekoljubne namene so Sefardi namenili velik del dohodkov. Zgovorni primer je sefardska družina Hardoon, ki je ustanovila več šol, med drugim tudi univerzo, kjer so poučevali tako kitajske klasike kot tudi zahodno znanost. Oktobra 1920 je Silas Hardoon prejel odlikovanje kitajske vlade, saj je zgradil internate za 500 kitajskih otrok. Poleg tega je s svojo kitajsko ženo, ki je bila budistka, posvojil 11 kitajskih sirot ter finančno podpiral še 100 drugih otrok. Milijone je družina Hardoon darovala v dobrodelne namene v času lakot v različne dele Kitajske. Druga judovska skupnost, ki je po številnosti prekašala Sefarde, pa je v Šanghaj emigrirala iz Rusije (Freyeisen 2000, 401-3).

Če so Sefardi prišli v Šanghaj zaradi gospodarskih priložnosti, pa so ruski Aškenazi bežali pred pregonom. Prvi ruski Aškenazi so v Šanghaj prispeli na prelomu stoletja. Po odprtju mandžurske železnice leta 1895 je mnogo ruskih Judov v Mandžuriji našlo bolj prijazno okolje kot v Rusiji. Večina jih je ostala v Mandžuriji, nekaj se jih je podalo tudi na jug v Tianjin (天津) in Šanghaj. Prvi ruski judovski priseljenci v Šanghaju so prihajali iz vrst vojakov, ubežnikov iz sibirskih zaporov ter političnih beguncev, zato so naleteli na neprijazen sprejem uglednih sefardskih veljakov. Ukvarjali so se s sumljivimi posli, npr. z razpečevanjem drog, trgovino $\mathrm{z}$ belim blagom ter odpiranjem barov $\mathrm{v}$ sumljivih mestnih četrtih. To je še poglobilo kulturni in socialni prepad med Bagdadi in ruskimi Aškenazi. Največji val ruskih Aškenazov pa je sledil Oktobrski revoluciji 
v Rusiji. Poražena bela garda je masovno emigrirala iz Rusije. Med begunci je bilo tudi mnogo Judov. Na Kitajskem so zatočišče našli večinoma $\mathrm{v}$ Mandžuriji, Harbin (哈尔滨) se je s prihodom ruskih emigrantov hitro razvijal. Nekateri begunci so zatočišče iskali tudi $\mathrm{v}$ priobalnih kitajskih mestih, vključno $\mathrm{s}$ Šanghajem. Po japonski okupaciji Mandžurije v začetku tridesetih let je sledila množična selitev Rusov na jug, predvsem v mesti Shenyang 沈阳 in Dalian (大连). $\mathrm{V}$ tem času je tretji večji val ruskih imigrantov, vključno z Aškenazi, dosegel Šanghaj. Število ruskih Judov je v tridesetih letih doseglo 4000 ter močno preseglo Sefarde. Približno četrtina vseh Rusov v Šanghaju je bilo Judov. Do tridesetih let dvajsetega stoletja je bil Harbin središče vzhodnoazijskega judovskega življenja, po prihodu nemških emigrantov pa mu je primat prevzel Šanghaj. Ruski Aškenazi niso dosegli blagostanja sefardskih magnatov, kljub temu pa so se sčasoma uvrstili $\mathrm{v}$ srednji in nižji srednji razred ter večinoma delali $\mathrm{v}$ malih podjetjih. Toda Japonsko-kitajska vojna je tudi na šanghajske Ruse slabo vplivala, mnogi so se morali spopadati $\mathrm{z}$ revščino. $Z$ naraščanjem števila ruskih Aškenazov je tudi ta skupina organizirala svoje šole in sinagoge.

\section{Potek emigracije Judov iz Tretjega rajha do leta 1938}

Po Novembrskih pogromih so šanghajske medije preplavile novice o grozodejstvih v Tretjem rajhu. Z zaskrbljenostjo so se spraševali, kakšne posledice bo prineslo zaostrovanje razmer v Nemčiji položaju v Šanghaju. Naraščajoče število Judov v Šanghaju, prisotnost stranke NSDAP ter politično zavezništvo Berlin-Tokio so prebivalce navdajali s strahom. Prve emigrante so prebivalci prisrčno pozdravili in jim pripravili topel sprejem. Ko pa se je njihov pritok nenadzorovano širil, so tudi mednarodne koncesije omejile priseljevanje. (Freyeisen 2000, 390).

Emigracija judovskih Nemcev v Šanghaj je potekala po dveh poteh. V prvi fazi do 10. junija 1940 pretežno po morskih poteh, v drugi fazi od 11. junija 1940 do 7. decembra 1941 pa prek transsibirske železnice. Begunci so večinoma potovali z italijanskimi čezoceankami. Pred začetkom vojne je bila možna tudi pot z nemškimi čezoceanskimi linijami. V prvem polletju leta 1939 so bile vse vozovnice za Šanghaj razprodane 6 mesecev vnaprej. Nekatere ladijske družbe so beguncem zaračunavale tudi do desetkrat višje cene za vozovnico kot običajno, saj so vedele, v kakšni stiski so. Ker so bile za judovske emigrante na voljo le vozovnice v prvem razredu, je nemška judovska organizacija Hilfsverein der deutschen Juden pogosto doplačala razliko do cene za prvi razred. Morska pot je običajno vodila iz italijanskih pristanišč v Trstu, Genovi, Benetkah ali v Neaplju 
prek Egipta, Bombaja ter Hong Konga v Šanghaj. V Egiptu je emigrante na krovu pozdravila judovska organizacija, ki jim je razdelila poletna oblačila ter druge potrebščine. Potniki na nemških ladjah so namesto plovbe skozi Sueški prekop potovali okrog Rta dobrega upanja. Begunci so večtedensko pot opisali kot pozitivno izkušnjo, saj so si lahko končno oddahnili in pozabili na vsakodnevni teror v domovini (Kranzler 1976, 86-88).

Junij 1940 je prinesel za nekaj tisoč Judov bridko razočaranje, saj so bile njihove vozovnice in tranzitni italijanski vizumi razveljavljeni. Italija je z vstopom v vojno na strani sil osi zaprla Sredozemsko morje, zato je bila edina možna pot na Daljni vzhod po kopnem. Zaradi obstoječega pakta o nenapadanju med Hitlerjem in Stalinom je bila zadnja rešilna bilka beg prek Sovjetske zveze. S transsibirsko železnico so nekateri prek Vladivostoka dospeli v japonski Kobe, tisti brez vizuma so pot nadaljevali prek Harbina do Daliana, od koder so se vkrcali na ladjo za Šanghaj. Junija 1941 se je z napadom Nemčije na Sovjetsko zvezo zaprla tudi ta pot. Kljub temu pa je zadnjim beguncem uspelo doseči Šanghaj do decembra leta 1941 (Kranzler 1976, 89).

Iz znanih razlogov se je le nekaj sto Judov leta 1933 odločilo za emigracijo v Šanghaj. Prvih 300 beguncev je bilo v veliki prednosti pred kasnejšimi emigranti, saj takrat še ni potekal proces arizacije ${ }^{5}$. Tudi državljanske pravice so jim bile zagotovljene. Prišleki so si v Šanghaju hitro našli zaposlitev in brez večjih pretresov preživeli vojno. Prvi begunci so bili večinoma dobro izobraženi akademiki, zdravniki, odvetniki ter inženirji. Judovski zdravniki so po številu prekašali svoje »arijske« predhodnike, zato so ti rohneli, češ da ne bodo dovolili "pojudenja« kitajskega zdravstva. Le dve družini nemških Judov sta do leta 1936 potrebovali socialno pomoč. Po letu 1935, ko so v veljavo stopili Nürnberški zakoni, je sledil novi val beguncev v Šanghaj. Drugi val beguncev je bil nekoliko večji kot prvi, saj je dosegel število 1000 . V tem času tudi mediji in različne judovske organizacije Šanghaja še niso promovirale kot možnega kraja za emigracijo. Za emigracijo v Šanghaj so se odločali predvsem tisti, ki se niso želeli ukvarjati z neskončno birokracijo, ki je bila potrebna za večino drugih ciljnih držav. Pogosto so v Šanghaj prispeli tudi odpuščeni izobraženci, ki niso imeli sorodnikov v tujini. Leta 1936 so se judovske publikacije v Tretjem rajhu začele zanimati za Šanghaj kot možni cilj emigracije. Največji judovski časopis v Nemčiji pa je šele leta 1938 informiral judovsko prebivalstvo o tej možnosti.

\footnotetext{
${ }^{5}$ Proces razlastitve in prenosa premoženja Judov na nemške lastnike.
} 
Zaradi posledic slabe informiranosti kot tudi zaradi osebnih preferenc je do Novembrskih pogromov v Šanghaj prispelo le okrog 1500 beguncev iz Tretjega rajha (Freyeisen 2000, 391-95).

\section{Položaj po letu 1938}

Velika večina judovskih emigrantov je v Šanghaj prispela po Novembrskih pogromih. $\mathrm{V}$ primerjavi s preostalimi ciljnimi državami je šanghajska emigracija potekala pozno in ni enakomerno razporejena po letih. Za šanghajsko emigracijo je zato značilna izkušnja terorja $\mathrm{v}$ Tretjem rajhu. Velik del emigrantov je po novembrskih pogromih doživel internacijo $\mathrm{v}$ koncentracijskih taboriščih ali $\mathrm{v}$ uradih gestapa. Interniranci v taboriščih Dachau in Buchenwald so bili praviloma izpuščeni že jeseni istega leta, če so jim bližnji kupili vozovnico ali če jim je uspelo dobiti vizum za emigracijo. Druga značilnost šanghajskega eksila je bila, da emigranti Šanghaja niso dojemali kot kraj stalne naselitve. Okrog $90 \%$ emigrantov je izjavilo, da ne nameravajo ostati v Šanghaju. Največ emigrantov je v Šanghaj prispelo konec leta 1938 in v letu 1939. Samo do junija 1939 se jih je izkrcalo okrog 15.000. Poleg tega so bili ti emigranti popolnoma obubožani. Prisilna arizacija judovskega premoženja je bila $\mathrm{v}$ tem času v polnem teku. Za nakup vozovnice za aretiranega družinskega člana so bližnji pogosto porabili zadnje prihranke. Revnejši sloji si niti vozovnice v tujino niso mogli privoščiti. Tisti, ki so imeli sorodnike v tujini, so lahko po postanku v Italiji prejeli nakazilo in si tako olajšali življenje v eksilu. Po zakonu so lahko emigranti na pot vzeli le borih 10 oz. 20 mark, zato so nekateri v kovčkih skrivali denar ali vrednejše predmete. Hitlerjeva politika prisilne emigracije je $\mathrm{v}$ upanju, da bo $\mathrm{s}$ tem antisemitizem izvozila $\mathrm{v}$ tujino, namenoma oropala Jude vsega premoženja (Freyeisen 2000, 390-401).

7000 šanghajskih emigrantov je prihajalo iz Nemčije in 4000 Avstrije. Nekaj sto jih je bilo iz Italije in Češkoslovaške. Kakih 1500 pa jih je imelo druga državljanstva ali pa so bili brez državljanstva. Okrog 1200 poljskih Judov, ki so pribežali v Šanghaj, se ima za preživetje zahvaliti japonskemu in nizozemskemu konzulu v litovskem mestu Kovno (današnji Kaunas). V prvi polovici leta 1941 je nizozemski konzul Jan Zwartendijk Judom, ki so iz Poljske množično pribežali v Litvo, izdajal vizume za nizozemski karibski otok Curaçao. To je storil na lastno pest, saj je vedel, da je sprejem Judov odvisen od odločitve guvernerja otoka, ki je načeloma zavračal možnost sprejema beguncev. Zwartendijk je izdal okoli 1500 vizumov za otok Curaçao, japonski veleposlanik Chiuné Sugihara pa je za te 
vizume izdal tranzitno japonsko vizo. Tudi posameznikom brez nizozemskega vizuma je izdajal tranzitne vize za Japonsko. S temi vizumi so lahko begunci potovali skozi Sovjetsko zvezo. Sugihara in Zwartendijk sta, kot kaže, delovala iz humanitarnih vzgibov. Sugiharo so zaradi nemškega protesta kmalu odpustili, po nekaterih navedbah naj bi tudi na dan odhoda $\mathrm{z}$ veleposlaništva izdajal tranzitne vize. V Kobeju na Japonskem so več kot 2000 beguncev v začetku lepo sprejeli, toda po zaostrovanju odnosov z ZDA in zaradi protesta nacistične Nemčije pri japonskih zaveznikih Judom jeseni 1941 niso več podaljšali veljavnosti vizuma. Kakih 1500 Judov je uspelo emigrirati v druge države, preostale Jude pa so Japonci deportirali v Šanghaj (Freyeisen 2000, 399).

\section{Razmere v šanghajskem eksilu}

V Šanghaju so bile zaradi številnih razlogov razmere za begunce veliko težje kot v ostalih večjih begunskih središčih v Evropi in v ZDA. Imigrante so pestile številne bolezni, poleg tega je razmere zaostrovala dolgotrajna Kitajsko-japonska vojna. Večina beguncev po letu 1938 je bila skoraj brez sredstev in zato so bili popolnoma odvisni od humanitarnih organizacij. Več kot polovica jih je bila nastanjena $\mathrm{v}$ begunskih centrih ${ }^{6}$, ki pa so bili prenatrpani in $\mathrm{v}$ katerih so vladale katastrofalne higienske razmere. Kljub tem težkim življenjskim razmeram pa se je v šanghajskem eksilu razvilo živahno kulturno življenje, ki je vnašalo optimizem ne le v življenje beguncev, temveč tudi vseh drugih prebivalcev Šanghaja.

\section{Omejitve priseljevanja}

Pri omejevanju priseljevanja v Šanghaj so imele prste vmes tako svetovne velesile kot tudi mednarodne judovske organizacije. Hud pritisk na begunce so izvajali tudi šanghajski tujci. Predvsem nižji sloji ruskih emigrantov so se počutili ogrožene, saj jim je množičnost beguncev pomenila hudo konkurenco. Tleči antisemitizem med tujimi prebivalci Šanghaja je tudi pripomogel k omejevanju priseljevanja. Tudi šanghajski nacisti so skušali prek antisemitske propagande med kitajskim in japonskim prebivalstvom razširiti antisemitizem. Toda to ni bistveno vplivalo na odnose med Kitajci in begunci. Drugi pomembni razlog za slab odnos tujcev do beguncev je bila izguba družbenega prestiža belcev. Belci so bili navajeni vladati, zato bi morebitno fizično delo beguncev pomenilo izgubo te družbene vloge (Kranzler 1976, 151-53).

\footnotetext{
${ }^{6}$ Teh begunskih centrov se je prijelo nemško ime Heim.
} 
Japonska je bila nesporno najbolj vplivna velesila v Šanghaju. Brez njene privolitve ni bil izveden noben ukrep. Zato tudi omejitve priseljevanja niso stopile v veljavo, dokler jih ni blagoslovila Japonska. Pritok beguncev se je zaradi nevtralne drže Japonske do Judov nadaljeval kljub pritisku mednarodne skupnosti. Povod za uvedbo restrikcij avgusta 1939 ni prišel od zunaj, temveč se je porodil znotraj japonske skupnosti v Šanghaju. Višanje cen najemnin v japonski četrti Hongkou, povečanje konkurence ter pomanjkanje stanovanj je vznemirilo japonske prebivalce četrti Hongkou. V letu 1939 se je zgodil preobrat japonskega obravnavanja Judov, saj je več japonskih časopisov objavilo protijudovske članke. Japonci so dolgo odlašali z uvedbo restrikcij zaradi bojazni pred kritiko v ZDA in Veliki Britaniji. Ko jim je sam Sir Victor Sasoon zagotovil, da podpira omejitve priseljevanja in da to ne bo vplivalo na javno podobo Japoncev v ZDA, so le izvedli prve restrikcije. 9. avgusta 1939 so v veljavo stopile prve omejitve. S tem se je končala doba brezvizumskega režima Šanghaja, ki je kot zadnji priprl vrata judovskim beguncem. Tisti begunci, ki so že bili na poti, so lahko prišli v Šanghaj brez omejitev, kasnejši begunci pa so morali izpolniti enega izmed naslednjih štirih pogojev: posedovanje 400 ameriških dolarjev kot garancijo, ozka sorodstvena vez s prebivalcem Šanghaja, pogodba o zaposlitvi v Šanghaju ali poroka s prebivalcem Šanghaja. V japonski četrti so se tega dogovora držali bolj striktno kot v Mednarodni naselbini. Ker večina imigrantov ni imela dovolj denarja, so nakazila običajno opravili sorodniki v ZDA ali pa humanitarne organizacije, ki pa so od imigrantov zahtevale, da po prihodu vrnejo 300 dolarjev za kasnejše begunce. Na pritisk Japoncev je SMC 1. julija 1940 zaostril pogoje. Poleg že obstoječih pogojev so morali imigranti izpolniti posebno prijavnico in šele s potrditvijo izpolnjevanja pogojev s strani mestne policije ter z nakazilom 400 dolarjev eni izmed šanghajskih bank so se lahko vkrcali na ladjo za Šanghaj. Po teh restrikcijah je le redkim uspelo po morju priti v Šanghaj, saj je Italija dober teden kasneje vstopila v vojno. S tem so bile dovolilnice za vstop v Šanghaj 2000 nemških Judov neveljavne. Le še nekaj sto beguncem je pod zaostrenimi pogoji uspelo iz Nemčije prek Sibirije priti v Šanghaj. Zadnji imigranti so bili poljski Judje leta 1941, ki jim je japonski konzul Sugihara rešil življenje (Kranzler 1976, 267-76).

\section{Zaostritev razmer po japonski okupaciji mednarodnilh enklav}

8. decembra 1941 je Japonska le nekaj ur po napadu na Pearl Harbor napadla britansko vojaško ladjo blizu Šanghaja. Zatem je sledila bliskovita zasedba 
celotnega Šanghaja. Tujci se niso upirali očitno premočnemu nasprotniku. Kljub zagotovilom, da se življenje v Šanghaju ne bo spremenilo, pa je okupacija Šanghaja močno prizadela vse Šanghajčane. Vsi tujci, ki so bili državljani Japonski sovražnih držav, so si morali nadeti trakove z napisom »Enemy National«. Nadzor nad vsemi tujimi podjetji so prevzeli Japonci. Bančni računi tujcev so bili zamrznjeni, dovoljeni so bili le minimalni dvigi za preživetje. Uvedena je bila stroga cenzura medijev. Čez nekaj dni so se morali vsi britanski in ameriški državljani registrirati pri japonskih oblasteh. Paradoksalno so imeli begunci brez državljanstva boljši status kot državni sovražniki. Toda to je veljalo le na papirju, revščina se je med njimi drastično povečala, saj so mnogi begunci izgubili službe v tujih podjetjih. Tuji poslovneži so bili prezaposleni z reševanjem svojih podjetij, da bi skrbeli za begunce, poleg tega pa jim z zamrznjenimi računi niso mogli pomagati (Kranzler 1976, 453-55). Najpomembnejši razlog za humanitarno katastrofo pa je pomenila prekinitev stikov z ZDA. Začetek pacifiške vojne je presekal humanitarno pomoč ameriških organizacij, izvozno naravnana Šanghajska podjetja pa so izgubila pomembne trge in v naslednjih letih morala trgovati le znotraj ozemlja pod japonsko okupacijo. Že v prvi fazi japonske okupacije leta 1937 je Šanghaj izgubil pomemben stik s kitajskim zaledjem, po letu 1941 pa so se razmere močno poslabšale. Inflacija je skokovito naraščala, potem ko se je zaupanje $\mathrm{v}$ valuto marionetne vlade $\mathrm{v}$ Nanjingu zmanjševalo. Razmerje med ameriškim in kitajskim dolarjem se je med letoma 1939 in 1942 desetkrat povečalo v prid ameriškega dolarja. Do konca vojne je inflacija dosegla vrtoglave vrednosti. Tudi tisti, ki so imeli službe, s plačo niso mogli preživeti niti sebe (Kranzler 1976, 455-58).

Za judovske begunce je vojna med Japonsko in zavezniki poleg prekinitve dotoka pomoči šanghajskih Sefardov in ameriških humanitarnih organizacij pomenila tudi spremenjen odnos Japoncev do nemških beguncev. Judovski imigranti so bili za Japonsko koristni le pri ohranjanju dobrega odnosa z ZDA. Ker pa po vstopu ZDA v vojno ni bilo več razloga za previdno ravnanje $\mathrm{z}$ judovskimi begunci, je Japonska spremenila politiko do emigrantov v Šanghaju. Odslej je vsakršno humanitarno pomoč morala odobriti pisarna za judovske zadeve, ki je bila $\mathrm{v}$ japonskih rokah. Kljub velikemu izpadu finančne pomoči so se številni begunci naučili sami poskrbeti zase. Nekaj hrane so sami pridelali na vrtovih okoli heimov. Socialni delavci so na vseh koncih poskušali pridobiti sredstva. Ker je ameriški politični vrh zavračal komunikacijo s sovražnikom, socialni delavci ameriških humanitarnih organizacij niso mogli prejemati denarja od matične 
organizacije. Kljub temu jim je uspelo ilegalno dobiti posojilo v švicarskih frankih. Med donatorji so bili tudi premožnejši šanghajski Kitajci in ruski Aškenazi. Organizacija $\mathrm{HICEM}^{7}$ s sedežem v Londonu je skrbela za komunikacijo s svojci v Evropi ter nakazovala majhne donacije najbolj potrebnim (Kranzler 1976, 464-68).

\section{Kultura v šanghajskem eksilu}

Prihod beguncev je ponovno oživil kulturno dogajanje v Šanghaju, ki je po japonski okupaciji začelo pešati. Revno in v letih 1932 in 1937 deloma porušeno četrt Hongkou so begunci preoblikovali v »mali Dunaj«, saj so odpirali številne kavarne, restavracije in slaščičarne. Med begunci je bilo veliko kulturnikov, ki so $\mathrm{s}$ pevskimi in igralskimi večeri skrbeli za svetle trenutke v sivem vsakdanu vojne. Izhajale so številne publikacije beguncev, med katerimi je izstopal kulturni list Gelbe Post, ki se je trudil zgraditi most med evropsko in kitajsko kulturo. Najbolj živahno kulturno dogajanje pa se je odvijalo na šanghajskih odrih. Prednjačili so kabareti, operete in komedije, dve resnejši drami Fremde Erde in Die Masken fallen pa lahko uvrstimo med vrhunce šanghajskega eksila. Tematizirali sta realne izkušnje terorja v Tretjem rajhu in težke razmere v mednarodno obarvanem Šanghaju. Ker pa sta bili vezani na specifično zgodovinsko situacijo v Šanghaju, sta močan vtis pustili le v času šanghajskega eksila. Podobno lahko trdimo tudi za celotno prepoznavnost šanghajskega eksila znotraj širšega zgodovinskega konteksta. Šanghaj je v vojnih razmerah skoraj 20.000 judovskim beguncem ponudil zatočišče, kar ga uvršča med večje emigracijske centre med Drugo svetovno vojno.

\section{Šanghajski geto}

Mnogi judovski begunci so imeli dokaj dobro mnenje o Japoncih. Predvsem poljski Judje so imeli dobre izkušnje z Japonsko zaradi Sugihare in toplega sprejema v Kobeju. Zdelo se je, da so Hitlerjevi azijski zavezniki odporni na njegov uničevalni antisemitizem. Toda begunci po vstopu ZDA v vojno niso bili več vzvod za pozitivno podobo Japonske v ZDA in nacistična Nemčija je vedno bolj pritiskala na Japonsko glede »judovskega vprašanja«. Po decembru 1941 se je sicer povečal nadzor Japoncev nad begunci in ulice so bile polne japonskih vojakov. Toda isto je veljalo za vse ostale tujce razen japonskih zaveznikov. Prvi

\footnotetext{
${ }^{7}$ Judovska človekoljubna organizacija, ki se je osredotočala na pomoč pri emigraciji evropskih Judov. Nastala je po združitvi treh organizacij leta 1927, in sicer je akronim treh organizacij: ICA, HIAS ter Emigdirect.
} 
očitni kazalnik spremenjene japonske politike je bila serija antisemitskih člankov poleti 1942. Če so bili nemški poskusi, da bi vplivali na japonsko politiko do Judov, do Pearl Harborja neuspešni, pa so po vstopu ZDA v vojno padli na plodna tla. Nemško veleposlaništvo $\mathrm{v}$ Tokiu je izdajalo antisemitske publikacije $\mathrm{v}$ japonščini, razširila so se antisemitska predavanja. Šanghaj so preplavili antisemitski članki, celo predsednik japonske marionetne vlade v Nanjingu Wang Jingwei (汪精卫) se je podpisal pod antisemitski članek o judovskem izčrpavanju Kitajske in Japonske. V japonskih šolah se je začela antisemitska indoktrinacija, judovske publikacije v Harbinu so bile ukinjene. Po vojni je leta 1951 nemški konzul v Tianjinu (天津) Fritz Wiedemann pričal (Diekmann 2012) ${ }^{8}$, da Japonci niso gojili antisemitskih čustev in da je zaostritev japonske politike do Judov povzročil pritisk nacistične zaveznice. Šlo naj bi za stalno Hitlerjevo prakso izvajanja rednega pritiska na zaveznice ter svetovanje pri političnih odločitvah (Kranzler 1976, 477-88). V tem kontekstu je mogoče razumeti tudi pritisk nemškega veleposlanika Josefa Meisingerja iz Tokia, ki je 1942 obiskal Šanghaj ter zahteval »dokončno rešitev judovskega vprašanja«. Toda Japonci iz različnih razlogov niso v celoti upoštevali njegovega nasveta, saj kljub vojni z ZDA niso želeli dodatno vznemirjati Američanov (Zhang in Wang 2011, 27). Josef Meisinger, ki je bil pred tem vodja varšavskega gestapa, kjer se ga je prijelo ime Varšavski klavec, je kmalu po nastopu funkcije veleposlanika na Japonskem pozornost usmeril na Šanghaj. Neslavnemu imenu, ki se ga je prijelo na Poljskem, se tudi na Daljnem vzhodu ni izneveril. Njegova žena je po vojni pričala, da je julija 1942 s podmornico prispel v Šanghaj. Tam se je srečal z japonskimi diplomati, s policijo ter $\mathrm{z}$ vodjo pisarne za judovske zadeve. Po navedbah japonskega vicekonzula naj bi predlagal naslednje:

Zavoljo našega zavezništva menimo, da bi se morali znebiti celotne judovske nadloge v Šanghaju. Ni se vam treba ukvarjati z izvedbo, mi bomo uredili vse podrobnosti. Vi boste le poželi uspehe našega dela. Seveda boste podedovali vso judovsko lastnino in od njih prevzeli nadzor. (Freyeisen 2000, 470).

Zatem je Meisinger Japoncem razkril svoje načrte. Čez dva meseca, ko Judje praznujejo praznik roš hašana, bi obkolili sinagoge. Na tej točki je Meisinger predlagal več možnosti. Jude bi lahko vkrcali na ladje in jih poslali na odprto morje, lahko bi jih zaprli v zapuščene rudnike soli, kjer bi umrli od lakote. Najbolj

\footnotetext{
${ }^{8}$ Kot so pokazale najnovejše raziskave, je Wiedemann pred prihodom na Kitajsko sodeloval z Angleži in ga lahko štejemo kot enega zgodnejših pripadnikov vojaškega odpora proti nacizmu.
} 
zloglasen načrt pa je bila gradnja koncentracijskega taborišča po nemškem zgledu na otoku Chongming (崇明岛) v estuariju Dolge reke severno od Šanghaja. Japoncem je predlagal izvajanje medicinskih poskusov in predložil natančne načrte koncentracijskega taborišča. Prisotni japonski slušatelji so predlog sprejeli različno. Japonski vicekonzul je kmalu zatem sklical krizni sestanek vodilnih judovskih organizacij in jih obvestil o morilskih načrtih nacistov, ker se je bal, da bi preostali prisotni resnično začeli izvajati ta načrt. Judovske organizacije pa so izrabile zgledne odnose z nekaterimi vodilnimi predstavniki japonskih oblasti ter preprečile najhujše. Ni jasno, ali je Meisinger za te načrte prejel neposreden ukaz iz Berlina. Po mnenju Astrid Freyeisen je bila njegova naloga nadzor nad judovskimi begunci v Šanghaju, vsi morilski načrti pa naj bi služili njegovim ambicijam. Bil je namreč vpleten $\mathrm{v}$ številne afere, zato je bil pripravljen za izboljšanje svoje podobe v Berlinu storiti marsikaj. Ustanovitev šanghajskega geta je bila zanj velik uspeh, zato je bil nekaj dni pred razglasom povišan v polkovnika policije. Očitno so v Berlinu za ta japonski ukrep zasluge pripisali Meisingerju (Freyeisen 2000, 470-75).

\section{Razglasitev šanghajskega geta}

Čeprav nacisti verjetno niso sodelovali pri razglasitvi šanghajskega geta in pri konkretnih operativnih vprašanjih, pa je njihov vpliv na spremembo japonske politike več kot očiten. 18. februarja 1943 so bile govorice o getu, ki so krožile med begunci, dokončno potrjene. Prek radia in prvih strani časopisov so Japonci razglasili šanghajski geto. V t. i. »označeno območje« so se morali vsi begunci brez državljanstva preseliti do 18. maja 1943. Za prodajo, najem ali nakup stanovanj, podjetij ali drugih ustanov zunaj označenega območja so begunci morali zaprositi za dovoljenje japonskih oblasti. Ostalim ljudem se ni bilo dovoljeno preseliti v označeno območje brez dovoljenja japonskih oblasti. Za kršitelje so bile zagrožene stroge kazni. Japonci so se $\mathrm{v}$ razglasu namenoma izognili besedama »geto« in »Judje« ter ti dve besedi nadomestili z »označeno območje« in »begunci brez državljanstva«. Ta evfemizma je bilo treba uporabljati tudi v zasebnih pogovorih, saj je bila omemba geta kazniva. Japonci so podrobneje pojasnili, koga mislijo z evfemizmom »begunci brez državljanstva«. To so bili begunci po letu 1937 iz Nemčije, Avstrije, Češkoslovaške, Madžarske, (nekdanje) Poljske, Latvije, Litve ter Estonije, ki so v tem času izgubili državljanstvo. Jeseni leta 1941 je dopolnilo k zakonu o državljanstvu v Tretjem rajhu vsem Judom na begu odvzelo državljanstvo. Zaradi časovne definicije emigracije je več kot očitno, 
da gre za begunce iz Tretjega rajha. Ruskih Aškenazov ta razglas ni prizadel, saj so v Šanghaj emigrirali bistveno prej. Zdi se, da so se Japonci tudi po vstopu ZDA v vojno bali vznemiriti ameriško vlado, zato so se izogibali izrazom Judje in geto. Verjetno so se bali povračilnih ukrepov nad interniranimi Japonci v ZDA, zato so krmarili po srednji poti med voljo nemških zaveznikov in ZDA. Nekateri begunci, ki so imeli najeta stanovanja zunaj geta, so se morali preseliti $\mathrm{v}$ japonsko četrt Hongkou, kjer so bile razmere veliko slabše. Zaradi kompleksnega postopka pridobivanja dovolilnic za izhod iz geta so nekateri izgubili službe. Japonska vojaška vlada je želela, da bi okrog 100.000 kitajskih prebivalcev geta zapustilo to območje. Toda Kitajci so japonskim oblastem prekrižali načrte, saj se niso hoteli preseliti. Ko so Japonci poskušali uporabiti silo, so se Kitajci pognali na ulice in dosegli svoje. Judje so se z množico Kitajcev v getu počutili varneje. Sami bi bili preveč izpostavljeni in so se zato pridružili kitajskim protestom proti japonskim načrtom izselitve Kitajcev (Kranzler 1976, 489-92).

Območje, ki so ga Japonci določili za »označeno območje«, je bilo že pred tem gosto naseljeno. Na površini, manjši od ene kvadratne milje, je živelo okrog 120.000 ljudi. Geto se je nahajal v osrčju japonske četrti Hongkou, na severu se je končal z mejo Mednarodne naselbine, na jugu pa ni dosegel reke Huangpu. V dolžino je meril le dobre tri kilometre. Že po japonski zasedbi celotnega Šanghaja je bil vstop v mednarodno naselbino za nemške Jude oteženi in potrebovali so t. i. dovolilnice za most. ${ }^{9}$ Med begunci je bilo veliko mešanih judovsko-nemških parov, nekateri med njimi so zvito pretentali nacistično spodbujanje ločitev »arijcev« od Judov. »Arijci« so namreč dobili finančno pomoč nemške ambasade, če so se ločili od svojih judovskih partnerjev. Okrog 150 parov se je ločilo le z namenom, da črpajo denar za svoje družine v getu (Kranzler 1976, 492-96).

\section{Upori v getu}

Če so določeni begunci do leta 1943 gojili občutke hvaležnosti do Japoncev, saj so jim ti dovolili imigracijo, pa se je po ustanovitvi geta med begunci razvil odpor do japonskih okupatorjev. Nekaj beguncev je sodelovalo v tajni podzemni združbi Gemeinschaft der Demokratischen Deutschen in Shanghai, ki je bila ustanovljena po začetku Vojne na Tihem oceanu. Vodstvo so prevzeli zgodnji begunci pred letom 1935, ki so obdržali državljanske pravice. Dr. Paulik je bil nejudovski

\footnotetext{
${ }^{9}$ Meja med četrtjo Hongkou in Mednarodno naselbino je bila na potoku Suzhou, mostove pa so stražili japonski vojaki, prečkanje mostu je bila edina možna pot v Mednarodno naselbino, od tod ime dovolilnice za most.
} 
politični begunec, ki je imel stike znotraj nemških diplomatskih ${ }^{10}$ ter celo vojaških krogov. Begunski člani te organizacije so se na dogovorjenih mestih srečevali z nejudovskimi sočlani. Ti so jih med drugim obvestili, da Japonci nameravajo zaseči vse radijske sprejemnike $\mathrm{v}$ getu, zato so jih mnogi begunci lahko pravočasno skrili. Radijski sprejemniki so bili glavni vir informacij za begunce. Zelo pomembna informacija, do katere se je dokopal antinacistični oficir nemške pomorske obveščevalne službe je bila obstoj vohunov znotraj geta, ki jih je gestapo poslal v Šanghaj že v času množičnega priseljevanja. Begunci so tudi sodelovali pri reševanju ameriških pilotov iz japonskega zapora, ki so jih pomagali spraviti do kitajskega zaledja. Nekateri begunci so sodelovali s kitajskim odporniškim gibanjem, ki se je predvsem osredotočalo na sabotažo japonskih tovarn in drugih objektov. Ruski Judje so sodelovali z Američani pri uničevanju japonskih zalog goriva ter pri usmerjanju ameriških letal na japonske tarče (Kranzler 1976, 530-35).

\section{Poslabšanje življenjskih razmer v getu}

Heterogena skupnost beguncev se je z getoizacijo poenotila $\mathrm{v}$ boju proti silam osi. Ko so po radiu slišali za poraz nemške vojske v Stalingradu, jih je to navdalo z upanjem, saj je bil čas na njihovi strani. Toda začetek leta 1944 je pomenil najtežje obdobje eksila. Lakota se je zaostrila, saj je ameriški organizacija za pomoč judovskim beguncem vedno težje zbirala denar. V tem času so begunci prodali celo svoje edine srajce za pest riža. Begunski otroci so skupaj z revnimi kitajskimi vrstniki tekmovali za ostanke gnilega sadja na tržnici. Revščina je dosegla celo tako skrajnost, da je 20 mater svoje novorojence prodalo za preživetje družine. Predvsem pozimi so bile razmere neznosne, saj so mnogi begunci prodali svoje obleke. 102 prebivalca heimov sta zaradi podhranjenosti umrla decembra leta 1943. V začetku leta 1944 je organizacija Kitchen Fund, od katere je bilo odvisnih od 5000 do 6000 beguncev, zmanjšala dobavo hrane na en obrok na dan, kar je begunce pahnilo na rob podhranjenosti. Otroci ter bolni in ostareli so zvečer prejeli še en obrok. Kasneje so se razmere nekoliko izboljšale zaradi reorganizacije humanitarnih organizacij in zaradi prvih osvoboditev koncentracijskih taborišč, ki so povečale donacije humanitarnim organizacijam. Hud udarec za begunce pa se je zgodil 17. julija 1945, ko so ameriške zračne sile bombardirale Šanghaj. Že od januarja 1945 so ameriški bombniki preletavali in občasno bombardirali kitajsko

\footnotetext{
${ }^{10}$ Najvidnejši diplomat, ki je bil član te organizacije je bil že omenjeni konzul v Tianjinu Fritz Wiedemann, ki je imel stike v najvišjih krogih nacistične oblasti.
} 
obalo. Na območju med Šanghajem in Nanjingom so bile njihove tarče razni vojaški objekti, skladišča, zaloge goriva, vojaške tovarne ter objekti za vojaško komunikacijo. Čeprav so imeli ameriški piloti ukaze, da ne smejo bombardirati civilnih območij, pa so občasno bombe zadele tudi civilne stavbe. Japonci so še vedno verjeli v teorijo, da za Judi stojijo ZDA in so zato strelivo shranili v getu Hongkou, saj so bili prepričani, da Američani ne bodo tvegali napada na geto. 17. julija pa so Američani izvedli najobsežnejše bombardiranje Šanghaja. Cilj ZDA je bila japonska radijska postaja, ki je koordinirala vojaško ladjevje. Radijska postaja se je nahajala v japonski četrti Hongkou. Dotrajane in slabo utrjene stavbe najrevnejše šanghajske četrti so se hitro vdale ameriškim bombam. Umrlo je 250 prebivalcev geta, med njimi 31 judovskih beguncev. Več kot polovica od 500 ranjenih je bilo beguncev, okrog 700 jih je ostalo brez strehe nad glavo (Kranzler 1976, 543-64). Časopis Shenbao, ki je bil v tem času že v japonskih rokah, je poročal, da je dvakrat v enem dnevu več kot 60 letal napadlo Šanghaj (Shenbao 1945).

\section{Konec vojne in ponovna emigracija}

Govorice o koncu vojne so se poleti 1945 okrepile, saj je ameriško letalstvo pogosteje preletavalo Šanghaj. Prek radiev, ki so jih begunci skrivali v getu, so izvedeli za odvrženi atomski bombi ter za vojno napoved Sovjetske zveze Japonski. Zatem so do konca avgusta vladale paradoksalne razmere. Nekajkrat so se begunci že veselili konca vojne, pa so jim japonske oblasti prekrižale načrte in niso dovolile prostega gibanja. Četudi je Japonska že prekinila z boji, pa je bil šanghajski geto osvobojen šele konec avgusta in 3. septembra so bile odstranjene zadnje postojanke, kar označuje tudi uradni konec geta. Po poročilu ameriških vojakov šanghajskega eksila ni preživelo 1726 beguncev, se je pa v tem času rodilo skoraj 300 otrok (Kranzler 1976, 566).

Poročilo komiteja za Daljni vzhod je maja 1946 naštelo še 16.000 beguncev v Šanghaju, 7380 nemških in 4298 avstrijskih. V začetku so bile možnosti emigracije v druge države majhne. ZDA so se striktno držale sistema kvot. Nekaj 1000 beguncev se je vrnilo v domovino, predvsem Avstrijcev. Nekaj 100 beguncev se je vrnilo v Berlin. Do oktobra leta 1946 je med 5000 in 6000 beguncev zaprosilo za ameriški vizum, od teh jih je le 600 prejelo odobritev. ZDA so bile na vrhu želja emigrantov zaradi prisotnosti svoje vojske v Šanghaju, ki je za begunce lepo skrbela. Nekaj jih je emigriralo $v$ Avstralijo in $v$ Latinsko Ameriko. Največ emigrantov pa je sprejela novoustanovljena država Izrael. Maja 
1948 ustanovljena judovska država je bila cilj predvsem religioznih beguncev. Konec leta 1948 in v začetku leta 1949 se je začela emigracija v Izrael. Sprva so se tja priselili predvsem ruski Aškenazi ter Bagdadi, pridružilo se jim je tudi nekaj beguncev iz Nemčije in Avstrije Po ustanovitvi Ljudske Republike Kitajske je v Šanghaju živelo še okrog 10.000 Judov. Po dogovoru med Izraelom in kitajsko vlado se jih je večina kmalu preselila v Izrael, leta 1957 jih je v Šanghaju ostalo le še kakih 100 (Buxbaum 2008, 179-82).

\section{Zaključek}

Pričujoči članek je poskušal osvetliti manj znani del judovske emigracije iz Tretjega rajha. Kalvarija judovskih beguncev pred nacizmom se je začela leta 1933, ko je Hitler izigral demokracijo in brezobzirno prevzel oblast. Postopno je nacistične sovražnike številka ena izločeval iz družbe. Z zlorabo zakonodaje je Jude oropal vseh pravic. Vajeni diskriminacije in antisemitizma niso slutili, kam vodi Hitlerjeva politika in iz različnih razlogov odlašali z emigracijo. Šele leta 1938 so uvideli, da jim nacistični režim zavezuje vrv okoli vratu. Po kristalni noči ${ }^{11}$ so bile mednarodne koncesije v Šanghaju edini košček zemlje, ki jih je bil pripravljen sprejeti. Konglomerat različnih narodov v Šanghaju je lahko v miru sobival le z načelno nevtralnostjo, zaradi tega je bil Šanghaj do beguncev gostoljuben. Toda begunci, oropani vsega premoženja, so bili popolnoma odvisni od tuje pomoči. Tudi Šanghaj je tako kot celotna Kitajska preživljal hude čase. Povrh vsega je Jude v Šanghaju ogrožal tudi režim v Berlinu, katerega lovke so segale do Šanghaja. Pritisk stranke NSDAP na japonske zaveznike je povzročil izgradnjo šanghajskega geta, le strahospoštovanje Japoncev do ZDA je morda preprečilo pomor judovskih beguncev v Šanghaju. Življenje emigrantov v getu je bilo najtežje obdobje šanghajskega eksila, bili so potisnjeni na rob preživetja, mnogim ni uspelo preživeti tega obdobja. Toda kljub trpljenju, strahu, pomanjkanju in drugim nadlogam so si begunci osmislili življenje s kulturo. Živahno kulturno dogajanje v šanghajskem eksilu sicer ni doseglo svetovne slave, je pa mnogim vsekakor pomagalo prebroditi najtežje obdobje svojega življenja. Gledano iz širšega zgodovinskega konteksta lahko opazimo globoko zakoreninjen antisemitizem in rasizem, ki je takrat preveval ves svet. Le Šanghaj je ponudil

\footnotetext{
${ }^{11}$ Pogrom nad Judi v Nemčiji in v delih Avstrije, ki se je zgodil 9. in 10. novembra 1938. Nasilje, aretacije, požige sinagog, trgovin ter drugih poslopij v lasti Judov je izvajala paravojaška enota SA (Sturmabteilung). Kristalna noč označuje pomembno prelomnico v zgodovini holokavsta, saj se s tem dogodkom začne sistematično iztrebljanje judovskega prebivalstva.
} 
roko beguncem in predstavlja zadnjo rešilno bilko za skoraj 20.000 življenj. Ta del zgodovine si vsekakor zasluži vidnejše mesto v evropski zavesti.

\section{Literatura}

Benz, Wolfgang. 2004. Was ist Antisemitismus? München: C. H. Beck.

—. 2008. Geschichte des Dritten Reiches. Bonn: Bundeszentrale für politische Bildung.

Buxbaum, Elisabeth. 2008. Transit Shanghai. Ein Leben im Exil. Wien: Edition Steinbauer.

Diekmann, Florian. 2012. "Hitlers Front-Vorgesetzter konspirierte mit Briten." Spiegel

Online, 17. Avgust, http://www.spiegel.de/panorama/hitlers-vorgesetzter-im-1weltkrieg-warnte-briten-und-amerikaner-a-850712.html

Freyeisen, Astrid. 2000. Shanghai und die Politik des Dritten Reiches. Würzburg: Königshausen und Neumann.

Goetz, Ariane. 2004. Exil in Shanghai - Über Fremdheitserfahrungen in den Autobiographien deutscher Exilanten. München: GRIN Verlag.

Graml, Hermann. 1998. Reichskristallnacht. Antisemitismus und Hudenverfolgung im Dritten Reich. München: Deutscher Taschenbuch Verlag.

Hawks Pott, Francis L. 2008 (1928). A Short History of Sanghai. Beijing: China Intercontinental Press.

Jahn, Hajo, ur. 1998. Zwischen Theben und Shanghai. Jüdische Exilanten in ChinaChinesische Exilanten in Europa. Berlin: Oberbaum.

Kranzler, David. 1976. Japanese, Nazis \& Jews: the Jewish refugee community of Shanghai, 1938-1945. New York: Yeshiva University Press.

Kugelmann, Cilly in Jürgen Reiche, ur. 2006. Heimat und Exil - Emigration der deutschen Juden nach 1933. Frankfurt am Main: Jüdischer Verlag im Suhrkamp Verlag.

Reitlinger, Gerald. 1961. Die Endlösung. Hitlers Versuch der Ausrottung der Juden Europas 1939-1945. Berlin: Colloquium Verlag Otto H. Hess.

Saje, Mitja. 2004. Zadnja dinastija in izzivi sodobnosti. Ljubljana: Filozofska fakulteta Univerze v Ljubljani.

Wang, Jian 王健. 2010. Shanghai de youtai wenhua ditu 上海的犹太文化地图 (Šanghajski zemljevid judovske kulture). Shanghai: Shanghai jinxiu wenzhang chubanshe.

Zhang, Yanhua 张艳华 in Jian Wang 王健. 2011. Kongjian, gushi, Shanghai youtai ren: Tilanqiao de guoqu yu xianzai 空间, 故事, 上海犹太人: 提篮桥的过去与现在 (Prostor. Zgodbe. Šanghajski Judje: Preteklost in sedanjost Tilanqiaoa). Nanjing: Yilin chubanshe. 